\title{
Managing Customers Relationships in Slovenian Companies*
}

\author{
Iča Rojšek ${ }^{* *}$
}

In the past two decades, the relationship between suppliers and customers has undergone a considerable changing process all over the world: both parties place a greater emphasis on the search for synergies in mutual relationships, sincere conversation and trust nurturing. The tendency to cut the number of suppliers is also evident. All stated and also other factors have inevitably led to major changes in the area of business-to-business marketing. We intent to point out some of these changes and also to examine responses of the Slovenian manufacturing businesses studied to the changes. The analytical part of the paper is based on a research project that has been carried out on the sample of fifty Slovenian manufacturing companies by the Faculty of Economics in Ljubljana for the past three years.

Während der vergangenen beiden Jahrzehnte hat das Verhältnis von Lieferanten und Kunden auf der ganzen Welt einen nachhaltigen Veränderungsprozess durchlaufen: auf beiden Seiten wird ein höherer Wert auf Synergien im gegenseitigen Verhältnis gelegt. Dabei spielen Ehrlichkeit und Vertrauen eine wichtige Rolle. Außerdem wird eine Tendenz zur Beschränkung der Anzahl der Lieferanten deutlich. Die genannten und andere Faktoren haben zu tiefgreifenden Veränderungen auf dem Gebiet des Business-to-Business Marketing geführt. Im vorliegenden Artikel werden einige dieser Veränderungen aufgezeigt. Außerdem werden die Reaktionen einiger slowenischer Produktionsbetriebe ausgewertet. Der analytische Teil der Arbeit basiert auf einem Forschungsprojekt mit fünfzig slowenischen Betrieben, das von der Fakultät für Wirtschaft in Ljubljana über die vergangenen drei Jahre durchgeführt wurde.

\footnotetext{
* manuscript received: 20.01.2000, accepted: 05.07.2000;

** Rojšek, Iča (1948); Associate Professor of Marketing; Faculty of Economics, University of Ljubljana, Slovenia. Main research topics: developing a market orientation; key account management; environmental management and green marketing; cause-related marketing.
} 


\section{Introduction}

In the past two decades, industrial buyers have radically changed their buying behavior and also their understanding of the suppliers' role, which can be explained by the recognition of the "win-win « exchange principle: no partner can make profit in the long run if the other partner is loosing at the same time. This shift is accompanied by the changing nature of relationships between buyers and customers; both parties place a greater emphasis on the search for synergies in mutual relationships, sincere conversation and trust nurturing. The tendency to cut the number of suppliers is also evident (McGinnis and McCarty 1998). Yet, until the early eighties the situation was quite different. A typical industrial buyer was using hard bargaining tactics and was buying inputs from a large number of suppliers; the basis for negotiations was price, contracts signed were short-term, but quality service and flexible manufacturing were nonetheless expected. Such buying behavior began to exhibit its obvious flaws. The "exploited" suppliers were not able to invest in new products and equipment; on the other hand, the buyers realized that their buying behavior led only to short-term savings and benefits, whereas at the same time the increasing competitive pressures forced them to innovate more rapidly and to conform to stricter quality and reliability standards, which could not be achieved without strong support from their suppliers. Operating with a large number of suppliers often led to unreliable inputs, complicated administrative procedures, and manufacturing complications (Matthyssens and Van den Bulte 1994). New discoveries about inventory-, manufacturing-, and quality-management also stimulated buyers to consider forming close relationships with their suppliers.

Industrial purchasing has evolved through the purchasing management to the purchasing chain management (Matthyssens and Van den Bulte 1994). Nowadays, the focus of purchasing is on managing all costs over the entire product life-cycle and it therefore considers not only the price but also the costs of financing, maintenance, delivery delays, poor quality, and the like. The emphasis is no longer only on price negotiations, but on matching one's own and supplier's competencies. The purchasing manager has assumed the role of the strategist in the supply chain: instead of waiting on potential suppliers' initiatives it acts proactively - it contacts suppliers and tries to persuade them to design products that fit its needs. The evolution of the purchasing function has led to a different comprehension of buyer-supplier relationships and to a shift toward more cooperative purchasing strategies, which consequently caused turnabouts in the area of business-to-business marketing.

The described worldwide developmental tendencies spontaneously stimulate rumination on relationships between Slovenian companies and their buyers. Several findings regarding this matter were gained through the research project Behavior of companies and financial institutions during the transition period that has been carried out by the Faculty of Economics in Ljubljana for the past 
three years. The sample of fifty manufacturing Slovenian companies employing over 250 employees has been drawn from the target population of 346 companies. The findings, presented in the paper, refer to the situation in the year 1996 and attempt to answer the following questions:

- What is the ratio between the number of new buyers and the number of lost buyers and what is the relative importance of both groups (in terms of their total annual sales revenue contribution)?

- What is the percentage of loyal customers in the customer portfolio of the companies studied?

- Is the so-called Pareto rule (better known as the " $80 / 20$ rule"), which implies that a relatively small number of buyers create a relatively large percentage of the total sales revenue, usually true?

- Do companies that exhibit a remarkable sales concentration on just a few important customers maintain more intense relationships with them, and can the manufacturing companies studied be sorted into clusters that differ according to the intensity of the relationships with customers?

In the paper we attempt not only to present and describe the research findings but also to point to their conceptual link with the customer management strategies pursued by companies.

\section{Retaining existing customers is more important than attracting new ones}

The traditional marketing approach focuses on attracting and keeping customers. But the marketing practice shows that companies consider attracting new customers to be somewhat more important than keeping the existing ones. This notion is also supported by our research results. Nearly two thirds of the companies stated that new customers, acquired in the year 1996, represented more than 5 percent of the total annual number of their buyers (more than a quarter of the companies studied even stated this percentage to exceed 10 percent) (Table 1). On the other hand, only 55 percent of the companies stated their new customers contributed more than 5 percent to the total annual sales revenue (Table 2), which is in fact not very surprising, for at the beginning of relationships customers usually tend to be somewhat incredulous of their new suppliers. According to the research results, at least a quarter of the companies in the sample were successful at acquiring new customers. However, this encouraging statement fades somehow if one considers the finding that nearly 28 percent of the companies studied lost more than 5 percent of their existing customers (in terms of numbers) in 1996 (Table 3), who at 28 percent of the companies generated more than 5 percent of the total annual sales revenue (Table 4). Both groups consist of mainly the same companies. 
Table 1. The percentage of new customers attracted in 1996 in the total number of customers

\begin{tabular}{|l|c|c|c|}
\hline & Frequency & Valid percent & Cumulative \% \\
\hline To $2.5 \%$ & 5 & 10.6 & 10.6 \\
\hline Above $2.5 \%$ to $5 \%$ & 12 & 25.5 & 36.2 \\
\hline Above $5 \%$ to $10 \%$ & 17 & 36.2 & 72.3 \\
\hline Above $10 \%$ & 13 & 27.7 & 100.0 \\
\hline Valid values & 47 & 100.0 & \\
\hline Missing values & 3 & & \\
\hline Total & 50 & & \\
\hline
\end{tabular}

Table 2. The percentage of new customers attracted in 1996 in the total annual sales revenue

\begin{tabular}{|l|c|c|c|}
\hline & Frequency & Valid percent & Cumulative \% \\
\hline To $2.5 \%$ & 8 & 17.0 & 17.0 \\
\hline Above $2.5 \%$ to $5 \%$ & 13 & 27.7 & 44.7 \\
\hline Above $5 \%$ to $10 \%$ & 16 & 34.0 & 78.7 \\
\hline Above $10 \%$ & 10 & 21.3 & 100.0 \\
\hline Valid values & 47 & 100,0 & \\
\hline Missing values & 3 & & \\
\hline Total & 50 & & \\
\hline
\end{tabular}

It is also interesting to note that there exists a semi-strong and positive correlation between the percentage of sales to new customers and the percentage of sales lost due to lost customers. The Pearson's correlation coefficient $(0.50)$ is statistically significant $(\mathrm{p}<0.01)$ and the null hypothesis (that the two variables are not linearly associated) may be rejected. One can therefore conclude the two variables to be linearly associated, which in our case indicates that the larger the proportion of sales to new customers, the larger the proportion of sales lost due 
to lost customers. According to the research findings, one may have reason to believe that companies, which are otherwise successful in attracting new customers, do not pay much attention to retaining their existing buyers as loyal customers.

Table 3. The percentage of customers lost in 1996 in the total number of customers

\begin{tabular}{|l|c|c|c|}
\hline & Frequency & Valid percent & Cumulative \% \\
\hline To $1 \%$ & 11 & 23.4 & 23.4 \\
\hline Above $1 \%$ to $2.5 \%$ & 5 & 10.6 & 34.0 \\
\hline Above $2.5 \%$ to $5 \%$ & 18 & 38.3 & 72.3 \\
\hline Above $5 \%$ & 13 & 27.7 & 100.0 \\
\hline Valid values & 47 & 100.0 & \\
\hline Missing values & 3 & & \\
\hline Total & 50 & & \\
\hline
\end{tabular}

Table 4. The percentage of customers lost in 1996 in the total annual sales revenue

\begin{tabular}{|l|c|c|c|}
\hline & Frequency & Valid percent & Cumulative \% \\
\hline To $1 \%$ & 18 & 38.3 & 38.3 \\
\hline Above $1 \%$ to $2.5 \%$ & 7 & 14.9 & 53.2 \\
\hline Above $2.5 \%$ to $5 \%$ & 9 & 19.1 & 72.3 \\
\hline Above $5 \%$ & 13 & 27.7 & 100.0 \\
\hline Valid values & 47 & 100.0 & \\
\hline Missing values & 3 & & \\
\hline Total & 50 & & \\
\hline
\end{tabular}

New customers are undoubtedly welcome to a company, but one should keep in mind that the existing customers are often more profitable. Numerous researches carried out by different authors worldwide - focused mainly on service 
industries - pointed out the following most important arguments to support this notion (Gronroos 1990; Page et al. 1996; Vavra 1992; Zeithaml et al. 1996):

- Replacing lost customers with new ones requires major marketing communications investments - acquiring a new customer usually requires significantly much more time, money and effort compared with keeping an existing customer;

- Loyal customers usually purchase larger quantities than other customers and their orders tend to be regular, which among other things simplifies the production planning process;

- Loyal customers tend to be less sensitive to their supplier's price changes than others;

- Due to word of mouth communications, loyal customers tend to attract new customers to their supplier, thus resulting in additional sales for the supplier.

It would be useful for Slovenian companies to determine reasons for losing their customers. One particular American research (Whiteley 1991) namely shows, that in 70 percent of all cases, reasons for customers leaving their suppliers have nothing to do with their products but with some sort of blunders in customer service and in customer relationships.

\section{Some customers are more important to a company}

Some of the ascertainments mentioned earlier already indicate the economic value of a loyal customer to the company. A simple calculation enables one to understand the value of a customer who remains loyal the entire lifetime or - in case the buyer is an organization - the entire span of its existence from the selling company's point of view: life time value of a customer = average transaction value $x$ yearly frequency of purchase $x$ customer "life expectancy". So, the question posed is very simple: "How many of the customers that we had 12 month ago do we still have today?" The answer to such a question can be complemented by an estimation of the loyal customers' purchases value, which enables a company to determine its success in increasing this value.

Similar issues were also referred to by our research. The companies studied were asked the following question: "What is the proportion of customers that have been loyal to your company for at least as long as 5 years in the total number of your customers?" The research shows an encouraging result that at half of the companies studied, more than three quarters of the customer base consisted of customers that had been purchasing from the same company for at least five years (Table 5). Somewhat less than two thirds of the companies stated that these regular customers generated more than 75 percent of the total annual sales 
revenue. More than one fifth of the companies even stated that regular customers contributed more than 90 percent to their total annual sales revenue (Table 6).

Table 5. The percentage of customers purchasing for at least 5 years in the total number of customers in 1996

\begin{tabular}{|l|c|c|c|}
\hline & Frequency & Valid percent & Cumulative \% \\
\hline To $50 \%$ & 11 & 22.0 & 22.0 \\
\hline Above $50 \%$ to $75 \%$ & 14 & 28.0 & 50.0 \\
\hline Above $75 \%$ to $90 \%$ & 20 & 40.0 & 90.0 \\
\hline Above $90 \%$ & 5 & 10.0 & 100.0 \\
\hline Valid values & 50 & 100.0 & \\
\hline Missing values & 0 & & \\
\hline Total & 50 & & \\
\hline
\end{tabular}

Table 6. The percentage of customers purchasing for at least 5 years in the total annual sales revenue in 1996

\begin{tabular}{|l|c|c|c|}
\hline & Frequency & Valid percent & Cumulative \% \\
\hline To $50 \%$ & 6 & 12.2 & 12.2 \\
\hline Above $50 \%$ to $75 \%$ & 11 & 22.4 & 34.7 \\
\hline Above $75 \%$ to $90 \%$ & 21 & 42.9 & 77.6 \\
\hline Above $90 \%$ & 11 & 22.4 & 100.0 \\
\hline Valid values & 49 & 100.0 & \\
\hline Missing values & 1 & & \\
\hline Total & 50 & & \\
\hline
\end{tabular}

Loyal customers represent a company's valuable asset, which holds particularly true for companies operating under mature market conditions characterized by very slow sales rate growth of all suppliers in the market. Under these conditions, which are nowadays characteristic for many markets, the cost of attracting new customers is even higher. Modern businesses are therefore 
increasingly focusing on delighting their customers and transforming them into loyal customers. This is especially important when a company faces the fact that a small proportion of the total number of customers contributes a large proportion to sales and profits. The notion stated leads to the conclusion that those customers who affect the company's business much more than others must be treated differently.

Table 7. The percentage of customers generating about two thirds of the total annual sales revenue in 1996

\begin{tabular}{|l|c|c|c|}
\hline & Frequency & Valid percent & Cumulative \% \\
\hline To $10 \%$ & 14 & 29.2 & 29.2 \\
\hline Above $10 \%$ to $25 \%$ & 9 & 18.8 & 47.9 \\
\hline Above $25 \%$ to $50 \%$ & 14 & 29.2 & 77.1 \\
\hline Above $50 \%$ & 11 & 22.9 & 100.0 \\
\hline Valid values & 48 & 100.0 & \\
\hline Missing values & 2 & & \\
\hline Total & 50 & & \\
\hline
\end{tabular}

Through the research we also attempted to find out whether the so-called Pareto rule applies to the companies studied. The findings show that Pareto rule distinctly applied to almost 30 percent of the companies: such was the proportion of the companies in which 10 percent or less of all buyers generated about two thirds of the total annual sales revenue (Table 7). It could be said that the companies' very existence depended on these customers; therefore, one may assume that many of the companies considered these customers as strategically important. Researches carried out abroad (McDonald et al. 1997) indicate that among various customer attractiveness criteria the Pareto rule prevails. But focusing exclusively on the present sales volume to the key customers can be misleading, for one might overlook some potentially significant opportunity costs. It is namely also necessary to identify those customers that are expected to significantly increase their purchases in the future; establishing a firm position among the suppliers of the future market leader soon enough is one of the most important aspects of the key account management strategy; customers in growing industries deserve to be paid a greater strategic attention than customers in stagnating or declining industries. Last but not least, a customer can be considered strategically important even if the purchases made are not outstanding for their value. This for instance applies to reputable customers who 
can serve as a reference account and also to customers that enable a company to access a new market, attain new technological or marketing skills and the like.

\section{Do companies pay a greater attention to important customers?}

On the basis of the findings presented so far, it seemed reasonable to form the following hypothesis: companies where about two thirds of the total sales revenue come from a small numbers of customers, maintain more intense relationships with customers.

The research questionnaire included among others also the following seven variables in the form of attitude statements that relate to the intensity of customer relationships:

- In our company, employees from different functional areas regularly meet to discuss and share views and perceptions about what is happening at our buyers and final customers.

- We are familiar with our customers' characteristics well enough.

- We meet with our customers regularly to establish their needs and the changes that should be made to our offering in the future.

- When something important happens to a major customer, the news gets quickly spread across departments.

- We periodically review the likely effects of environmental changes on our customers.

- Customer satisfaction is measured on a regular basis.

- Customer satisfaction data are disseminated to all departments in our company.

All of the variables were measured on a five-point Likert scale (ranging from 1 $=$ strongly disagree to $5=$ strongly agree). They all proved to have very similar mean values. Table 8 shows that the variable Interdepartmental customer satisfaction data dissemination appears to have the lowest mean value (3.21) and the highest variability of scores, whereas the variable Regular meetings with customers achieved the highest mean value of 3.98. Kurtosis and skewness coefficients indicate normal distributions for all the variables, although all of them exhibit a slight asymmetry to the left.

The hypothesis stated above was tested using the bivariate correlation procedure. Attempts were made to estimate the association between the variables Intensity of customer relationships and The percentage of customers generating about two thirds of the total annual sales revenue. The first of the two variables was obtained by combining all 7 variables, relating to the intensity of customer relationships, into a Likert scale; for each case, the variables' values were first added and the sum was then divided by 7 . This procedure resulted in a new 
variable with values on the scale of 1 to 5; a higher value indicates more intense relationships with customers, whilst a lower value indicates less intense relationships. The new variable scored a mean value of 3.53 , a standard deviation of 0.58 and distributes normally.

Table 8. Basic statistics for variables relating to the intensity of customer relationships

\begin{tabular}{|l|c|c|c|c|c|c|c|}
\hline & $\begin{array}{c}\text { Valid } \\
\text { values }\end{array}$ & Mean & Median & Mode & $\begin{array}{c}\text { Std. } \\
\text { dev. }\end{array}$ & $\begin{array}{c}\text { Skew- } \\
\text { ness }\end{array}$ & $\begin{array}{c}\text { Kur- } \\
\text { tosis }\end{array}$ \\
\hline $\begin{array}{l}\text { Regular inter- } \\
\text { departmental } \\
\text { customer info. } \\
\text { Exchange }\end{array}$ & 50 & 3.30 & 4.00 & 4 & 1.09 & -0.44 & -0.61 \\
\hline $\begin{array}{l}\text { Familiarity with } \\
\text { customers } \\
\text { characteristics }\end{array}$ & 50 & 3.48 & 3.50 & 3 & 0.86 & -0.33 & 0.40 \\
\hline $\begin{array}{l}\text { Regular } \\
\text { meetings with } \\
\text { customers }\end{array}$ & 50 & 3.98 & 4.00 & 4 & 0.96 & -0.97 & 0.90 \\
\hline $\begin{array}{l}\text { Quick inter- } \\
\text { departmental } \\
\text { new info. } \\
\text { dissemination }\end{array}$ & 50 & 3.66 & 4.00 & 4 & 0.92 & -0.25 & -0.67 \\
\hline $\begin{array}{l}\text { Periodic review } \\
\text { of changes at } \\
\text { customers }\end{array}$ & 50 & 3.68 & 4.00 & 4 & 0.82 & -0.26 & -0.29 \\
\hline $\begin{array}{l}\text { Regular } \\
\text { measurement of } \\
\text { customer } \\
\text { satisfaction }\end{array}$ & 49 & 3.22 & 3.00 & 3 & 1.05 & -0.02 & -0.52 \\
\hline $\begin{array}{l}\text { Interdepart- } \\
\text { mental customer } \\
\text { satisfaction data } \\
\text { dissemination }\end{array}$ & 48 & 3.21 & 3.00 & 3 & 1.11 & -0.24 & -0.38 \\
\hline
\end{tabular}

The value of the Pearson correlation coefficient turned out to be 0.03 , which indicates no association between the two variables whatsoever. The finding does not support for our hypothesis that those companies, whose destiny depends heavily on a small number of customers, engage with them more intensively as compared with the companies where the Pareto rule is not as obvious. Such a 
finding, however, refers only to the companies sampled, since the significance level was to high to enable the generalization of the finding to the entire population of Slovenian manufacturing companies. The reason for such an unexpected research result can actually be attributed to the small sample size. It would certainly be much more concerning if a larger sample yielded the same result.

The research problem was also analyzed from another perspective based on the multivariate analysis. Cluster analysis was applied to form small groups of companies with different customer relationship intensity level. Two types of clustering methods were used: the Ward method of hierarchical clustering and the K-Means Cluster method. Clusters were formed on the basis of two groups of variables:

1) the group of variables, that relates to the intensity of customer relationships, consisted of the seven variables listed above (Table 8);

2) dependence of companies on customers was operationalized by the scale containing the following three attitude statements:

- Relatively few customers purchase the majority of our products.

- Our customer base does not change much from year to year.

- Our company is highly sensitive to the requirements of a few key customers.

These three variables were also measured on a five-point Likert scale (ranging from $1=$ strongly disagree to $5=$ strongly agree). Table 9 shows that the variables achieved similar mean values (they range from 3.46 to 3.68) and that they distribute normally.

The Ward's method of hierarchical clustering was used to establish that the companies studied could be most adequately grouped into three clusters (grouping companies into more clusters would result in too few cases in each cluster). The K-Means Cluster method, which was used subsequently, exposed the following characteristics of the three groups:

- CONSCIOUS (9 companies): companies in this group ascribed an above average value to most of the variables concerning intensity of customer relationships, whereas the value ascribed to the variables concerning dependence of companies on customers was below average. This group is relatively small, but nevertheless exceeds our expectations: Pareto rule does not apply to the companies in this group, their customers are not very regular, and companies do not particularly depend on them but they still maintain above average or at least average intense relationships with customers. Perhaps these are the companies that have set themselves a task of transforming as many of their present customers into loyal ones as they 
possibly can, since they have realized the importance of loyal customers to their businesses.

Table 9. Basic statistics for variables relating to the dependence of companies on customers

\begin{tabular}{|l|c|c|c|c|c|c|c|}
\hline & $\begin{array}{c}\text { Valid } \\
\text { values }\end{array}$ & Mean & Median & Mode & $\begin{array}{c}\text { Std. } \\
\text { dev. }\end{array}$ & $\begin{array}{c}\text { Skew- } \\
\text { ness }\end{array}$ & $\begin{array}{c}\text { Kurto- } \\
\text { sis }\end{array}$ \\
\hline $\begin{array}{l}\text { Relatively few } \\
\text { customers }\end{array}$ & 49 & 3.53 & 4.00 & 4 & 1.34 & -0.74 & -0.52 \\
\hline $\begin{array}{l}\text { Relatively stable } \\
\text { customer base }\end{array}$ & 50 & 3.46 & 3.00 & 3 & 1.07 & -0.41 & -0.05 \\
\hline $\begin{array}{l}\text { High sensitivity } \\
\text { to customer } \\
\text { requirements }\end{array}$ & 50 & 3.68 & 4.00 & 4 & 1.02 & -0.39 & -0.90 \\
\hline
\end{tabular}

- IGNORANT (12 companies): even though companies in this group assigned an above average score to each of the variables measuring their dependence on customers, they at the same time assigned a below average score to each of the variables measuring intensity of customer relationships. This group is in total contradiction with our expectations: although the companies have only a few mainly regular customers on whom they greatly depend, they maintain below average intense relationships with them. Obviously, these companies strongly believe in the well-known saying "till death do us part". It is possible that their customers currently have no alternative source of supply; however, in an opened and competitive economic environment this situation may change very quickly.

- MEDIOCRE (29 companies): the largest group of the companies is characterized by average values of most of the variables concerning the intensity of customer relationships as well as average values of all of the variables concerning their dependency on customers. This group actually corresponds to our expectations: the companies have a mediocre large number of customers that come and go and on whom they depend to a medium extent and companies maintain medium intense relationships with them. One might suspect these companies have not yet realized that - at least in the long run - some customers are relatively more important to the business and therefore deserve a different treatment. 


\section{Conceptual framework for customer management improvement}

The second of the groups of companies mentioned is especially concerning, since one might suspect these companies do not particularly concern themselves with finding means to retain important customers; maybe these companies overestimate the customers' barriers to switching the supplier and the magnitude of switching costs perceived by their customers. Such barriers can for example consist of the costs of searching for a new supplier, transaction costs, costs of learning, loyal customer discounts, customer habits, and, last but not least, emotional barriers. In short, the barriers consist of all the financial, social and psychological risks faced by a customer (Fornell 1992). Even if one takes into account the other two groups of companies, there are still no certain reasons for optimism, for these depend on the customers' satisfaction with the ways companies treat them. In the rest of the paper, the attention will therefore be paid to some important aspects of business-to-business marketing, which distinguish first-class companies from the mediocre ones.

Nowadays, the impetus for marketing seems to be the issue of establishing such relationships with customers that make them oblivious to alternative sources of supply. Relationship marketing has but only one final goal: designing such marketing strategies that enable the company to retain and even strengthen the loyalty of its customers. Even though numerous definitions of relationship marketing can be found in the literature, the concept was first introduced by Berry; he defined relationship marketing as "attracting, maintaining and enhancing customer relationships" (Berry 1983: 16). For the sake of comparison, let us also cite the broadened definition given by Morgan and Hunt. They define relationship marketing in a broader sense as "all marketing activities directed at establishing, developing, and maintaining successful relational exchanges" (Morgan and Hunt 1994: 21-22), which also refer to partners that are not consumers and can be found in internal as well as external company's environment.

The common thread of all definitions is a conceptual shift away from a strictly transactional and short-term exchange exhibited in Table 10. The majority of relationship marketing definitions namely emphasize mainly the long-range and lasting nature of relationships as opposed to the transactional, individual exchange activities. Some authors even believe the long-term relationships between suppliers and customers to be the only suitable marketing strategy due to the lower costs of doing business with regular customers as compared with attracting new ones (Žabkar 1999 and the sources qouted there).

Although our research did not attempt to specifically address the issue just discussed, several findings nevertheless do shed some light on this matter. When the companies studied were confronted with the issue of the basis for their key customers' purchasing orders, it turned out that although long-term contracts 
prevail (almost 45 percent of all answers), there is still a fairly large proportion of companies (almost 37 percent) that exhibit a distinct transactional orientation even toward the key customers; their business with the key customers is based on short- term contracts for a period shorter than one year or even on sporadic transactions (Table 11).

Table 10. The shift to relationship marketing

\begin{tabular}{|l|l|}
\hline \multicolumn{1}{|c|}{ Transactional focus } & \multicolumn{1}{c|}{ Relationships focus } \\
\hline Orientation to single sales & Orientation to customer retention \\
\hline Discontinuous customer contact & Continuous customer contact \\
\hline Focus on product feature & Focus on product benefits \\
\hline Short time scale & Long time scale \\
\hline Little emphasis on customer service & High customer service emphasis \\
\hline $\begin{array}{l}\text { Limited commitment to meeting } \\
\text { customer expectations }\end{array}$ & $\begin{array}{l}\text { High commitment to meeting customer } \\
\text { expectations }\end{array}$ \\
\hline $\begin{array}{l}\text { Quality is the concern of production } \\
\text { staff }\end{array}$ & Quality is the concern of all staff \\
\hline
\end{tabular}

Source: Christopher 1992: 12.

Table 11. The basis for the key customers purchase orders

\begin{tabular}{|l|c|c|c|}
\hline & Frequency & Valid \% & Cumulative \% \\
\hline Sporadic purchases & 4 & 8.2 & 8.2 \\
\hline $\begin{array}{l}\text { Short-term contracts (shorter } \\
\text { than one year) }\end{array}$ & 14 & 28.6 & 36.7 \\
\hline $\begin{array}{l}\text { Long-term contracts (longer } \\
\text { than one year) }\end{array}$ & 22 & 44.9 & 81.6 \\
\hline Long-term alliances & 9 & 18.4 & 100.0 \\
\hline Valid values & 49 & 100.0 & \\
\hline Total & 50 & & \\
\hline
\end{tabular}


Even though it is often stressed that a company operating on the basis of longterm relationships with customers and cooperating with them in designing products or services and coordinating marketing strategies may enjoy a number of advantages, one should not neglect the fundamental condition that has to be fulfilled - and that is trust. Trust exists when one party believes the other one to be a reliable partner and to fulfill the agreed (Žabkar 1999). Various researches pointed to the extremely important role of trust as a factor in enhancing the relationship between supplier and customer (Žabkar 1999, and the sources quoted there). Trust leads to commitment and cooperation, which serve as a basis for customer-supplier marketing relationships building.

Several distinguished authors (from the IMP - Industrial Marketing and Purchasing Group) pointed out the difference between relationship marketing and the interaction approach. The latter is namely especially characteristic for industrial marketing. Ford (1997) believes the essence of relationship marketing still to be a process that takes place between an active seller and a passive buyer, even though it differs significantly from the conventional consumer marketing due to the emphasis on stimulating repeat purchases (and therefore loyalty) by relatively identifiable customers. Industrial marketing process, however, is not one of action and reaction - it is characterized by interaction (Ford 1997). Industrial marketing namely relies on multi-person interactions between the buyer and seller companies' employees. It should also be noted that the process involves employees from various functional areas and not only marketing, sales or purchasing. Also, employees from the latter areas do not meet only once to close the deal (or to make a business transaction) and then never again. Weeks or even months of meetings, negotiations, product and production process development may sometimes (especially in case of initial purchase) proceed the final deal closure - all these activities require lots of interaction. Furthermore, the initial purchase may only be the forerunner of others, which may take place either uninterrupted (for example in case of production components) or at longer time intervals (for example in case of machine equipment); in both cases the employees involved at both parties will more or less keep in mind the occurrences that happened prior, during and after the purchase, which will probably affect the evolution of the next purchase. All this indicates that each purchase is but a single episode in the total relationships between the companies (Ford 1997).

Besides negotiations, communications are also the key factor in establishing and maintaining relationships between supplier and customer. Empirical researches show the quality and frequency of communications to have a positive impact on quality of relationships and on general satisfaction with relationships (Žabkar 1999, and the sources quoted there). Our research shows that manufacturing companies studied communicate with their key buyers fairly frequently, as more 
than three quarters of the companies stated to engage in communications several times per month or weekly (Table 12).

Table 12. Frequency of communications with key customers

\begin{tabular}{|l|c|c|c|}
\hline & Frequency & Valid \% & Cumulative \% \\
\hline $\begin{array}{l}\text { Several times per year } \\
\text { (monthly) }\end{array}$ & 11 & 22.4 & 22.4 \\
\hline $\begin{array}{l}\text { Several times per month } \\
\text { (weekly) }\end{array}$ & 38 & 77.6 & 100.0 \\
\hline Valid values & 49 & 100.0 & \\
\hline Total & 50 & & \\
\hline
\end{tabular}

Interpersonal contacts are especially valuable in managing customer relationships. They may serve various purposes: important is not only the information exchange - which is supposed to reduce uncertainty at both parties but also the social interaction. The latter may in fact result in promises and obligations between the persons involved, which may also prove to be beneficial to both respective companies. The majority of the Slovenian companies studied seem to be aware of the opportunities posed by social interaction with their customers, for more than three fifths of them stated they communicate with their key customers both formally and at social occasions (Table 13). But on the other hand, companies that favor formal communications at business occasions are also not that few in number.

Ford et al. (1998) point out the social interaction between employees of both companies (the selling and the buying one) to be a logical consequence of good contacts between functional areas or departments on both sides. If one attempts to limit social contacts in order to avoid provoking eventual problems (for instance in case a sales employee identifies more closely with the interests of the buying company than with those of his or her own company), many benefits associated with these contacts would also have to be given up. The need for interpersonal contacts is even greater if one is involved with a foreign customer. This holds particularly true in the early stage of the relationship development, when such contacts contribute to a better understanding of cultural, educational, technological and economical differences between the domestic and foreign environment. 


\section{A View from the Customers' Perspective}

Relationship marketing is not necessarily the best approach in each situation, nor can it be assumed that all customers prefer it. Customers should therefore be considered in order to find out whether they really favor the relationships building with their suppliers or they simply expect to be fully informed during the decision buying process. Such an analysis can be performed on the basis of the following matrix (Figure 1).

Table 13. The occasions of communicating with key customers

\begin{tabular}{|l|c|c|c|}
\hline & Frequency & Valid \% & Cumulative \% \\
\hline $\begin{array}{l}\text { Formal business } \\
\text { occasions prevail }\end{array}$ & 19 & 38.8 & 38.8 \\
\hline $\begin{array}{l}\text { Formal as well as social } \\
\text { occasions }\end{array}$ & 30 & 61.2 & 100.0 \\
\hline Valid values & 49 & 100.0 & \\
\hline Total & 50 & & \\
\hline
\end{tabular}

One extreme group consists of customers that exhibit a strong preference for close contacts with their suppliers; it is very important for them that a supplier is able to understand their company, problems, strategies, challenges, and plans. A supplier can contribute most to such a relationship by anticipating customers' needs and helping them to make the right decisions. This group usually consists of customers that have little knowledge and experience with the buying product and therefore expect their suppliers to advise them. At the other extreme there are customers with a strong need for information; they prefer suppliers who continuously inform and educate them, so they can keep abreast of the latest developments in their field. It is not unusual for these customers to know more about the product then the supplier itself.

The extent to which a customer values an in-depth business relationship with the supplier company can be determined on the basis of posing the customer the following questions:

- How important is it that people in our company know people in your company, and vice versa?

- To what extent do you want us to advise you on what decisions to make, based on our knowledge of your company and your needs?

- How important is it that we work to build a long-term, mutually beneficial relationship in which we work to achieve joint goals? 
To determine the extent to which a customer wants the supplier to provide information, the following questions should be asked:

- To what extent do you want us to keep you up-to-date on details regarding new products, discontinued products, price changes, service policies, and so on?

- How important is it that we help you gather, synthesize, and make sense of the complex information in your business, so that you can make good decisions?

- To what extent do you want us to inform you about industry trends, competition, and new technologies that might affect your business?

Figure 1. Value orientation frame

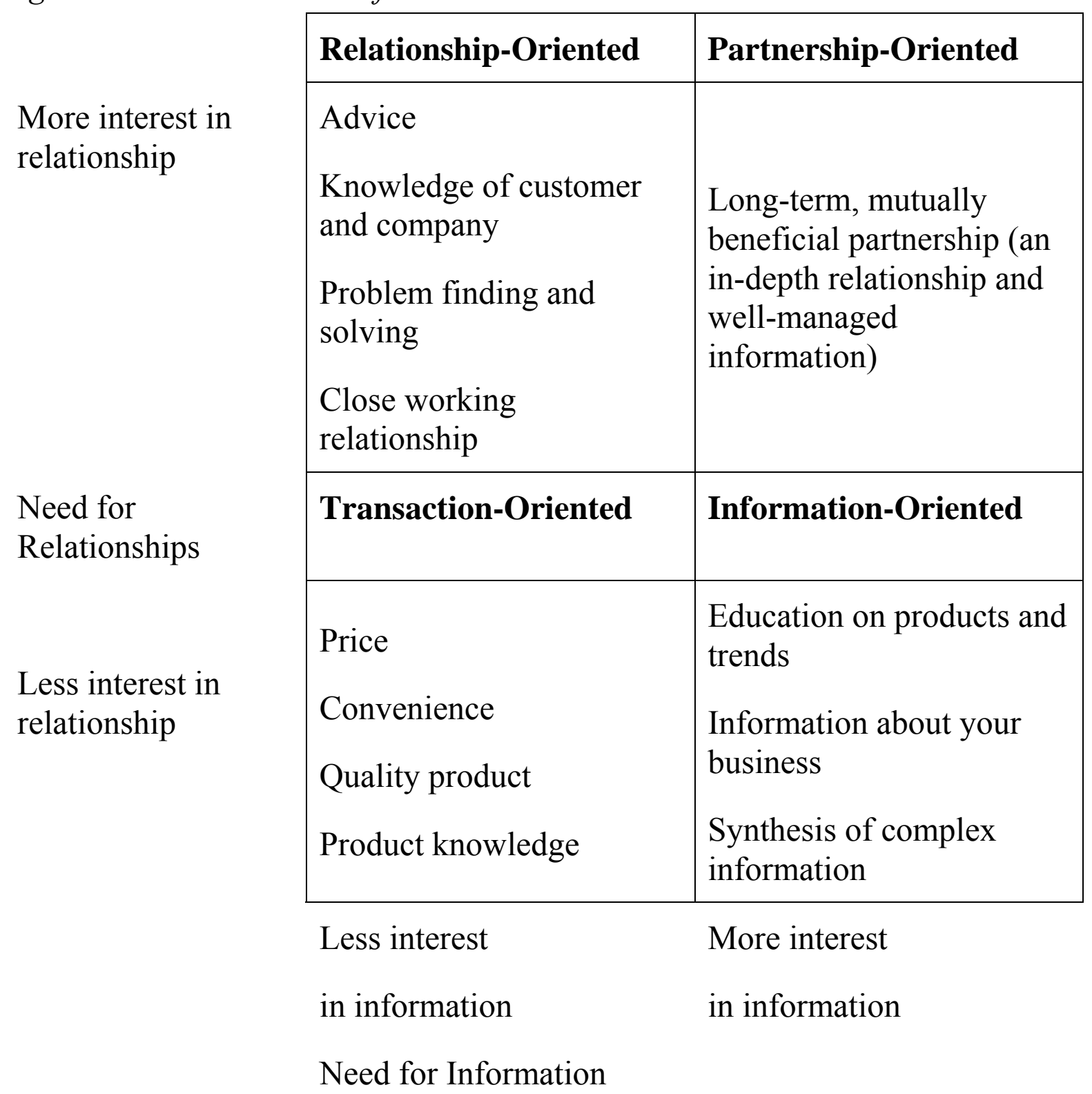

Source: Whiteley and Hessan 1996: 155. 
When designing key customers management strategy, the supplier must be aware of the customers' different purchasing strategies. Before the supplier company attempts to position itself as the preferred supplier, it should first of all assess the importance (technological and financial) of its product for each individual customer. Even though a supplier places a certain customer among strategically important customers, what really matters is whether the customer also considers the supplier important. An interesting classification of suppliers is done by Siemens - a company with 120.000 suppliers worldwide - which categorizes 20.000 of its suppliers as first class suppliers. The classification is based on two factors: the purchasing risk and profitability (Burnett 1992: 29-32). The purchasing risk is measured by the dependence on a particular supplier in terms of supplier's product technical complexity and market availability of suitable substitute. When assessing the importance of each supplier the company therefore attempts to answer the question: "What consequences would we bear if the supplier did not meet the standards required?" This question further relates to the following issues:

- How (non)standard is the product in question?

- What would the switching costs amount to?

- How complicated would it be for us to manufacture this product in-house?

- How many/few suppliers of this product/component exist?

According to this measure, suppliers of technologically challenging and differentiated products form one end of the continuum and suppliers of standardized products the other one.

As regards to this model, the supplier's impact on profitability is in proportion to the value of purchases or to the percentage of the specific component's or product's purchases in the total Siemens' value of purchases. Only as far as products with high monetary and technological value are concerned, the purchasing strategy is defined in terms of cooperation or partnership.

\section{Conclusion}

In this paper we have attempted to link several findings of our research study with theoretical issues and also with several foreign companies' experiences that unveil a new way of understanding business partnership and marketing in general. We focused mainly on the apparently simple relationship between two companies (the customer and the supplier). The reality is much more complicated for each company is involved in a network of relationships or interactions. The network consists of direct relationships that a company has with its customers and also with other organizations - as for example banks, marketing research agencies and the like. One of the components of the network are also relationships between the mentioned company's partners and their 
suppliers and customers. For instance, a major supplier of the company "A" has relationships with the other customers, which may also affect its relationship with the company "A". But things get even more complicated if one considers that the network surrounding the company " $A$ " consists also of indirect relationships between companies with which the company " $A$ " has no direct contacts, but can nevertheless indirectly influence its way of doing business. As an example, one might consider the relationship between two companies that also supply one of the customers of company "A". Occurrences in this fairly distant relationship (from the perspective of the company " $A$ ") may influence the requirements and opinions of the respective customer of the company " $\mathrm{A}$ " for instance regarding the quality of customer service, complaints' handling and the like (Ford 1997).

The fact that the company is only a kind of knot in the network of interactions which either directly or indirectly include the company or are even independent of the company, inevitably leads to the conclusion that business-to-business marketing cannot be based upon the assumption of a mass market or one that can be segmented into several distinctive segments. The market must be understood as a network of relationships between firms that are engaged in production, distribution and use of goods and services (Ford 1997). The marketing task is above all one of establishing, developing and maintaining these relationships; managing the traditional marketing mix (that is dealing with issues of product, price, placement and promotion) must be fully subordinated to this task.

\section{References}

Berry, L. L. (1983), "Relationships Marketing”, in: Berry L. L. et al. (Eds.), Emerging Perspectives in Services Marketing, Chicago: AMA, 25-28.

Burnett, K. (1992), Strategic Customer Alliances, London: Pitman Publishing.

Christopher, M. (1993), The Customer Service Planner, Oxford etc.: Butterworth Heinemann.

Ford, D. (ed.) (1997), Understanding Business Markets: Interaction, Relationships and Networks, 2nd Ed., London etc.: The Dryden Press.

Ford, D. et al (1998), Managing Business Relationships, Chichester etc.: John Wiley \& Sons.

Fornell, C. (1992), “A National Customer Satisfaction Barometer: The Swedish Experience”, Journal of Marketing, 56, pp. 6-21.

Gronroos, C. (1990), Service Management and Marketing, Lexington, MA: Lexington Books.

Matthyssens, P. and Bulte, C. Van den (1994) "Getting Closer and Nicer: Partnerships in the Supply Chain", Long-Range Planning, 1, pp. 72-83.

McDonald, M., Millman, T. and Rogers, B. (1997), "Key Account Management: Theory, Practice and Challenges", Journal of Marketing Management, 8, pp. 737-757.

McDonald, M. and Rogers, B. (1998), Key Account Management. Learning from supplier and customer perspectives, Oxford etc.: Butterworth-Heinemann. 
McGinnis, F. and McCARTY, L. (1998), "Strategic account management in the new procurement environment", Supply Chain Management, 1, (www.europe.emeraldlibrary.com/brev/17703ac1.htm).

Morgan R. M. and Hunt S. D. (1994), "The Commitment-Trust Theory of Relationship Marketing”, Journal of Marketing, 58 (3), 20-38.

Page, M. J., Pitt, L. F. and Berthon, P. (1996), "Analyzing and Reducing Customer Defections”, Long-Range Planning, December, pp. 821-834.

Vavra, G. T. (1992), Aftermarketing, Homewood: Richard D. Irwin.

Whitheley, R. C. (1991), The Customer-Driven Company. Moving from Talk to Action, Reading etc.: Addison-Wesley Publishing Company.

Whitheley, R. and Hessan, D. (1996), Customer Centered Growth, London: Century Ltd.

Zeithaml, V. A., Berry, L. L. and Parasuraman, A. (1996), "The Behavioral Consequences of Service Quality”, Journal of Marketing, April, pp. 31-46.

Žabkar, Vesna (1999), Trženjski odnosi na medorganizacijskih trgih profesionalnih storitev konceptualni model in empirična preverba. Ljubljana: Ekonomska fakulteta. 